ACTA UNIVERSITATIS LODZIENSIS

FOLIA LITTERARIA POLONICA 7(45) 2017

http://dx.doi.org/10.18778/1505-9057.45.10

Katarzyna Smyczek*

\title{
Irony, self-mockery, and ironic turns of events. Marian Załucki's satirical performances
}

Marian Załucki was a well-known artist on the Polish comedy scene. He was the co-creator of many radio and television shows, e.g. Podwieczorek przy mikrofonie, Zgaduj-zgadula, Poznajmy się. He performed original monologues in Krakow's Teatr Satyryków, Warsaw's Teatr Syren and Buffo theatre, and in the comedy groups Wagabunda, Dudek, and U Lopka. He collaborated with Przekrój, Szpilki, and Życie Literackie periodicals. Załucki's collections of poetry were published in high volumes.

It would seem that despite the fact that Załucki played an important role in the cultural life of the PRL ${ }^{1}$, in today's literary and historical space he is a somewhat forgotten figure. Texts devoted to the comedian mainly consist of memoirs of his friends, and comedians who collaborated with him. Ludwik Jerzy Kern was the main and an invaluable promoter of Załucki's output. Apart from a 2012 study entitled $Z$ mej poetyckiej natury. wiersze i fraszki Mariana Załuckiego ${ }^{2}$ by Józef Duk, there have been no other attempts at analysing the poet's texts.

Marian Załucki witnessed and experienced the repression of two major totalitarian regimes of the $20^{\text {th }} \mathrm{c}$. He was born on 5 May 1920 in Kolomyia in Eastern Borderlands. He participated in the September Campaign and fought in the battle of Mława. Upon the capitulation of Warsaw, he was placed in a Stalag. In December 1939, he managed to escape the POW camp, and reach the Soviet-occupied Lviv, where he remained until the end of the war to finally relocate to Krakow with the first repatriation wave. ${ }^{3}$

\footnotetext{
* Mgr, e-mail: smyczekkatarzyna@gmail.com, Department of $20^{\text {th }}$ and $21^{\text {st }}$ century Polish Literature, Faculty of Philology, University of Lodz, 91-404 Lodz, 171/173 Pomorska street.

${ }^{1}$ Commonly used abbreviation of the People's Republic of Poland.

2 J.A. Duk, Z mej poetyckiej natury. wiersze i fraszki Mariana Załuckiego, Wydawnictwo Astra, Lodz 2016.

${ }^{3}$ Ibid., pp. 5-6.
} 
In 1945, he lived in a tenement house at 22 Krupnicza St. ${ }^{4}$ Unfortunately, the Krakow branch of the Writers' Union was seeking a new seat at that time. It was decided that the most appropriate location for the people of letters was that particular tenement house. ${ }^{5}$ The writers decided unanimously - or rather, as reminisced by Ryszard Marek Groński ${ }^{6}$, led by one of them, i.e. Adam Ważyk - that in the "writers' kolkhoz" there is no place for citizens who do not belong to the collective. Thus Załucki was excluded from the writers' union even before being accepted into it.?

It is unclear whether the eviction from the flat in Krupnicza St. induced him to start a writing career ${ }^{8}$, but the comedian débuted that very year performing on the comedy stage, and publishing several satirical poems in Przekrój. He published his first collection of poetry 9 years later when writers were still bound by the guidelines of Socialist realism.

Załucki rather avoided "mainstream issues", yet the problematic patronage of the workers' party prevented creators from achieving complete political neutrality. Being a forced co-organiser of the reconstruction of the souls of Poles, through an assignment of that peculiar patron of the arts, he wrote a few satirical poems. An indication of their propaganda applicability could be the fact that they were included in the monumental Antologia satyry polskiej 1944-1955 published in 1955 by PIW.

The tasks of the "new" satire defined by literary journals did not leave writers too much freedom ${ }^{10}$. Authors could not always decide what would become the topic of a work, and writing commissioned by officers, who eagerly fulfilled the recommendations of the party, became in the 1950s the main literary practice ${ }^{11}$. That fact was humorously parodied by Marian Załucki in a poem entitled Sen satyryka:

The phone woke me up early...

Who's there? I asked.

This is the editorial office!

${ }^{4}$ R.M. Groński, O nim jako ulubieńcu publiczności (In celebration of the release of a record with Marian Załucki's poems, 2003), in: http://zalucki.net/wspomnienia/48-o-nim-jako-ulubiencupublicznosci (accessed on 13.10.2017).

${ }^{5}$ Ibid.

${ }^{6}$ Ibid.

${ }^{7}$ L.J. Kern, "Marian Załucki”, in: Moje Abecadłowo, Wydawnictwo Literackie, Krakow 2003, pp. 210-211.

${ }^{8}$ Ibid.

${ }^{9}$ R.M. Groński, op. cit.

${ }^{10}$ K. Alichnowicz, "Miejsce dla kpiarza" satyra w latach 1948-1955, Universitas, Krakow 2006, p. 142.

${ }^{11}$ Ibid., p. 143. 
We require an epigram. A short one.

Alas:

$\mathrm{S}-\mathrm{t}-\mathrm{o}-\mathrm{c}-\mathrm{k}-\mathrm{t}-\mathrm{a}-\mathrm{k}-\mathrm{i}-\mathrm{n}-\mathrm{g}$ ! (...)

Damn it! Drop the jokes!

Do you have an epigram?

I do, of course.

But... not a - p - p - r - a - i - s - e - d!

$*$

$\mathrm{Oh}$ - you sometimes fantasise like that

Or imagine at night in your dreams,

That you became a sales point of

$\mathrm{MHD}^{12} \ldots{ }^{13}$

Significantly enough, the poem appeared in the 1954 Przejażdzki wierszem collection, which also included reprinted Socialist realist satires written by Załucki and commissioned by party officials. The ironic tone of the dialogue with the official could induce one to doubt the poet's engagement in the ideological class struggle. By utilising metaphor and ambiguity, play on words and parody, Załucki indicated the absurdity of the new order.

The division line between the sacred and the profane was the place for a mocker, i.e. between that which was allowed and that which was banned. The poet was not an obvious oppositionist, yet neither did he clearly supported the authorities, which he proved many times by refusing to cooperate with the PRL's Security Service (SB)..$^{14}$

In Puszka z Pandora, Ryszard Marek Groński described Załucki’s tragic situation:

Let us get to the core of it. Now, (...) it was decided in the department of creative intelligentsia that it was necessary to acquire an informer. Someone approached the oblivious comedian. He offered to hold regular meetings. Simple, nothing special:

\footnotetext{
${ }^{12}$ MHD - Miejski Handel Detaliczny (Urban Retail Trade); a company established in 1948 pursuant to a Regulation of the Minister of Internal Trade. Its activities consisted of the retail trade of food stuffs and hardware. Direct supervision over the activities of the shops of the MHD chain was maintained by local authorities which in turn were supervised by the Ministry (vide Regulation of the Minister of Internal Trade of 27 May 1950, M.P.1950.A-68.811). The aim of the state's economic policy at that time was to limit the activities of private entrepreneurs. The restructuring of trade resulted in immense difficulties in acquiring everyday items as the liquidated private shops were not replaced with a sufficient number of state-owned facilities (vide http://muzhp.pl/ $\mathrm{pl} / \mathrm{e} / 1730 /$ bitwa-o-handel).

${ }^{13}$ M. Załucki, "Sen satyryka”, in: idem, Przejażdżki wierszem, Czytelnik, Warsaw 1954, p. 9. [English version translated from Polish]

${ }^{14}$ R.M. Groński, Puszka z Pandora, Polska Oficyna Wydawnicza „BGW”, Lodz 1991, p. 163.
} 
what is being said, what is going on, who came up with what while drunk...

The recruitment seemed easy. And suddenly-vexation. The young comedian refused. He was given time to reconsider. Yet he once again said: no. They mentioned by the way that they could get a ban on his publications, they could recommend seizure of his lump sum, finally, they could direct the case in such a way as to throw him out of the Writers' Union. And then, without a licence to perform a freelance job, he would become a parasite. And as a parasite he would not be able to live in Krakow (...) So if he wanted to condemn his family to a life of poverty and neglect, then go ahead: refuse the hand offered by the authorities.

The family argument was chosen well: the comedian was old-fashioned, homely, attached to his wife, and he adored his two little daughters. So the bottom line was that, through an exception, they would once again give him time to reconsider. But he could not even divulge a word of what was going on. Because otherwise... ${ }^{15}$

Harassment resulted in the comedian's nervous breakdown. ${ }^{16}$ He was referred to a hospital and was a patient of Antoni Kępiński ${ }^{17}$, one of the most renowned Polish psychiatrists. The doctor's status was supposed to shield Załucki from UB harassment. It turned out, however, that the serious threat to the poet's health posed no obstacle for the secret police officers:

Having regained some strength, he had to go for the talk once more. After it, he attempted to commit suicide. Having been saved, he received a visit still at the hospital. Not only did he refuse (how many times had he done it by then), but he also shouted at the officer clad in a white smock. A nurse came. The UB officer had to flee like hell. The Security Service decided to wait for the patient to get better. Then a surprise once again. Before he got better, he escaped from the hospital, and went to Warsaw. Everyone has some last resort. For the black-mailed poet, it was his colleague from school. A boy from Kolomyia, because that was the name of their town. Now the boy was the secretary of the State Council. ${ }^{18}$

${ }^{15}$ Ibid.

${ }^{16}$ In an article entitled "Moje kresy. Kołomyjski mistrz humoru", Stanisław S. Nicieja stated that his nervous breakdown was just malingering. Yet it is difficult to believe that the mental health of Marian Załucki was so strong that threats to his family and friends did not influence the poet's general health, and that he had to pretend his anxieties.

Vide http://www.nto.pl/apps/pbcs.dll/article?AID=/20131228/REPORTAZ/131229714, (accessed on 13.10.2017).

${ }^{17}$ Antoni Kępiński, a Polish psychiatrist and philosopher, the forerunner of group and individual psychotherapy in Poland; he participated in a programme of treating former Auschwitz internees; his major texts included: Refleksje oświęcimskie (1968), Rytm życia (1972), Melancholia (1974), Lęk (1977), Poznanie chorego (1978); (vide Słownik psychologów polskich, E. Kosnarewicz, et al. (eds.), Instytut Psychologii UAM, Poznan 1992, p. 112).

${ }^{18}$ R.M. Groński, op. cit., p. 164. 
Henryk Holder, the person mentioned above, was the director of the Legal Office of the Chancellery of the State Council in Bolesław Bierut's government. Immediately after WWII, Załucki's benefactor was the accuser in the trials of the members of the anti-communist underground. Accepting help from a person associated with repressive authorities could be read as morally ambiguous, but it was Holder's intervention with the UB management that released the poet from the need to choose between the life of a martyr and a label of a snitch.

Załucki's dramatic biography was reflected in his satirical output. Both on stage and in his poems, he created the character of a shy loser involuntarily sliding through life, a common citizen, one of many. The speaking persona in Załucki's works is both brave and cowardly. Lacking physical strength in an encounter with an omnipotent opponent, he could only win through the power of his mind. Satire directed against the authorities reached their weaknesses, extracted everything that somehow made them inferior as an opponent, smaller than it would seem. The hostility which for some reason could not emerge otherwise, could do so through jokes.

The poet concealed the criticism of the people's rule under the mask of selfmockery, which became his trademark. The author anticipated the accusation of a political betrayal of the ideals of the workers' party-how can one refuse a citizen his right to mock himself? By belittling himself, he mitigated and, at the same time, amplified his ironic stabs. A seemingly insignificant remark uttered using special stress can be more successful in drawing people's attention to the speaker's opinion than if it was expressed directly.

A negation of the literal meaning can lead to false reading of the intention of an expression. The risk of misunderstanding is part and parcel of ironic practices. ${ }^{19}$ Therefore, the poet felt obliged to act on the stage in Obrona autoironii [Defence of self-mockery]:

Oh, you cruel audience!

Oh, you -

who expect me to offer you

the flesh and blood

of Innocent Ministers

and their Sacred Wives -

go to hell!

Oh, excusez-moi (...)

Alas, dear young people,

I always rush at myself

with my mouth,

\footnotetext{
${ }^{19}$ Ibid.
} 
and down!

I know -

maybe I deserve it?

Maybe I will be the minister of culture?

Do not mock, then - please -

my self-mockery,

when I taunt myself,

when I myself use against me

my own weapon...

Oh, well - I like it

bold! $!^{20}$

Załucki proved that the edge of satire was like a boomerang: once thrown it came back to him but on its way back it nicked the intended people. The poet and the scoffer. Załucki provided a perverse defence of party VIPs. He justified their absence in his works in a rather absurd way: one of the dignitaries was supposed to appear in a poem, but he had a toothache, while the poet saved the rest for a rainy day. It was a long-term work plan: the bigger fish lay as a deposit in a drawer, waiting to be used if there were no better topics to choose from.

The poet achieved the comic effect by lexical charades - he toyed with lexical polysemy (ministers are saved for thriftiness), and paired (or combined in trios) in rhyming lexemes from completely different stylistic areas: $\dot{z} o n-w o n-$ pardon (wives - go to hell - excusez-moi). Through an accumulation of short lines, and masculine rhymes, the words are stressed, which further amplifies the satirical meaning of that seeming praise. The term sacred wives brings to mind the idiom of a sacred cow, which is used in Polish to refer to a person who considers herself/himself (or is considered by others) as not subject to criticism, regardless of the acts she/he engages in or refrains from engaging in. Those humorous textual cracks constituted a signal that the poet applied irony, and the defence of important figures was necessary.

In the 1956 period of political thaw, real socialism lost its status as the leading idea of artistic output. Utilising his greater freedom, Załucki took the liberty - or, in that context, it would be more appropriate to state that he was "given the liberty" - to utter slightly bolder statements, but he continued to utilise the poetics of Socialist realism ironically distorting it, as e.g. in the poems which offered a mocking defence of the ideals of the October Revolution, which he wrote during his trips beyond the Iron Curtain, of which the poet made quite a few... Załucki set off on his first international "tour" for the Polish commu-

${ }^{20}$ M. Załucki, “Obrona autoironii", in: idem, A nie mówiłem?, Iskry, Warsaw 1961, pp. 7-9. [English version translated from Polish]. 
nity in America in 1958. He travelled throughout his stage career. In 1965, he performed together with the "Wagabunda" comedy troupe for Polish emigres in London. The comedian's monologue made a particular impression on Marian Hemar:

(...) I would give first place to Marian Załucki. I was so proud to watch one more Lviv child, and listen to his neat, precise, and extremely amusing little poems. Such phenomena like Załucki are the crown jewels of the classic comedy show, which loves everything that is young, creative, and original. You can tell how much perfecting those little poems took, how their author polished and ground them, how much talent, craft, and joy he put into them; he seeks good rhymes, not being satisfied with the terse punchline, he creates situation/poems, sketch/poems, in which humour is graded per variants, and the consequences of surrealist logic, the grotesque is ever present, all the way to the absurd, It seems to me that Załucki is mainly a humourist who sees the world from its hilarious side, not a comedian who perceives the world from the side of fairness. His poems profit much from the fact that the author found his own style of delivery which he has not borrowed from anyone, nor does he mimic anyone. To fit it, he writes his poems, and turns them into absolutely amusing hits, (...) he would be the star of any comedy troupe, surely a stunner of the old Qui Pro Quo ${ }^{21}$.

Załucki's association with Qui Pro Quo was his love for the aesthetics of pure nonsense. Laughter usually accompanies the discovery of phenomena divergent from the standard. The juxtaposition of absurd situations which became the norm in Poland after 1945 and those which exist within non-people's democracies, and considering the former, following the mocking device à rebours, as a generally applicable norm, is used for uncovering the absurd elements ${ }^{22}$ of the PRL's reality. In a rather humorous way, Załucki matched the tradition of an educational journey. The persona of the creative activities was a constant failure, and even the Iron Curtain did not offer him a haven from his wretched fate. His story was inextricably linked (if not bound) with the motherland. His countrymen colonised every corner of the Earth and a piece of Mars, which is why coming into contact with a foreign culture had proved impossible for the traveller. He had no time for extensive studies of himself as everywhere he went he met Poles willing to confess to him. He brought the following conclusions from one of his foreign trips:

${ }^{21}$ M. Hemar, Awantury w rodzinie, Wydawnictwo LTW, Łomianki 2008, p. 304. [English version translated from Polish].

22 B. Dziemidok, O komizmie. Od Arystotelesa do dzisiaj, Monika Bokiniec (ed.), Słowo / obraz terytoria, Gdansk 2011, p. 131. [English version translated from Polish]. 
Terrible,

how small the Earth is...

There are Poles everywhere...

Humbly...

Because that's the Polish trademark:

during war - they're on all fronts,

during peace - they're in the backhouse..$^{23}$

Even though Poles are revolutionaries, and whatever their weapons would be, they win on all fronts, in the capitalist rat race they are defenceless. Thank god rhetorically, of course - for socialism. His travels were his opportunity to learn about Eastern and Western philosophies. The superiority of the former is indubitable. The inhabitants of western Europe do not appreciate martyrology, and they have been sabotaging the emancipation of the working class. For the protagonist, travelling meant mainly inconvenience, cruel necessity, and a punishment comparable to the exile from paradise. Even if Hell did not stand a chance when compared to the socialist world of the upside-down. When Załucki, following Dante, travelled the netherworld, he met a tormented countryman:

And even in Hell:

a little devil - a bellboy,

Lucifer's protégé...

Talked to me: sure he's Polish.

And that nostalgia is devouring him...

"I cried a lot of tears (he said),

when I went past the gate...

Because here - you see - it is hell, too,

but it's not the same..."24

Poles can adapt even to pandemonic conditions, and have a decent life there, thanks to their skills of contriving, and protection. In fact, as Załucki commented ironically, they learnt the art of survival in a country which made Hell seem more like a sin bin than a place of eternal ordeal of the souls of the condemned. In the socialist cosmos, all desires, even those nutritional, could be sinful and socially detrimental, which was why the citizens of the People's Republic could only dream about "nothing":

${ }^{23}$ M. Załucki, "Polacy wszędzie", in: idem, Czy lubi pani Załuckiego?, Iskry, Warsaw 1967, p. 188. [English version translated from Polish].

${ }^{24}$ M. Załucki, Polacy wszędzie..., p. 188. 
Take that which isn't.

Add salt and caraway, then mix with that which is currently not on the market.

Mix long and well stop when you get bored and sprinkle with that which we absolutely cannot afford.

You can either fry it or bake, or singe on a grill, pouring over with that of which you are not even allowed to dream!

Everyone here eats that there's enough for everyone, that is the secret of the Polish economic miracle. ${ }^{25}$

The recipe for the Polish economic miracle was published in 1974 in the Przepraszam, żartowatem collection. Unfortunately, the failure's fate, which became Załucki's way of his artistic life, did not leave the poet even after his death. Less than six years later, Przepis po polsku was printed without crediting him. The poem became extremely popular during the August strikes in the north of Poland. It was published in issue 4 of the Solidarność Strike Information Bulletin with a note:

The poems were brought in by anonymous authors. We shall include more in the following issues of Solidarność. ${ }^{26}$

The person who delivered the poem to the strikers surely did not possess its printed version because the version published in the Bulletin differed from the original in several places. ${ }^{27}$ That proves the considerable popularity if not

${ }^{25}$ M. Załucki, Przepis po polsku, in: idem, Kpiny i kpinki, L.J. Kern (ed.), Wydawnictwo Literackie, Krakow 1985, p. 336. [English version translated from Polish].

${ }^{26}$ Strajkowy Biuletyn Informacyjny "Solidarność", 25 August 1980, issue 4, http://www. wszechnica.solidarnosc.org.pl/?page_id=724 (accessed on 13.10.2017).

${ }^{27}$ Przepis po polsku, Strajkowy Biuletyn Informacyjny “Solidarność", 25 August 1980, issue 4. [English version translated from Polish].

Take this which isn't

Add salt and caraway

then mix with that which

is currently not on the market 
of Załucki himself then of his works, which were repeated by people as anonymous jokes.

Załucki, sympathising with the working class, displaying his original irony, commented upon everyday problems, which resulted from the party's wasteful governance of the country:

What kind of life is it

somewhere there in prosperity,

where everything works perfectly?

Where people can buy whatever they desire,

simply at a shop...

Like a fool!

Where when faced with brimming shop counters and displays

there is no joy in a kilogram of lemons! ${ }^{28}$

Comedy shows have always been a space for defying strict morality, and unwavering rigid social order; comedy show humour, particularly in Wilhelm's Germany, was a way of avoiding strict censorship, and the only place where political satire was practised. Comedy scripts often referring to current social problems had to fall under special surveillance of the PRL's censors. Though the objectives of the new satire in the 1950s was clearly defined, they became blurred in the following decades.

Shows which mocked the actions of the authorities were cancelled, and any remarks on the economic situation were censored. The authorities made sure that the Western living standard and economy did not seem better ${ }^{29}$. A Warsaw censor allowed the publication of the text of Ulica dowcip in a 1970 collection entitled

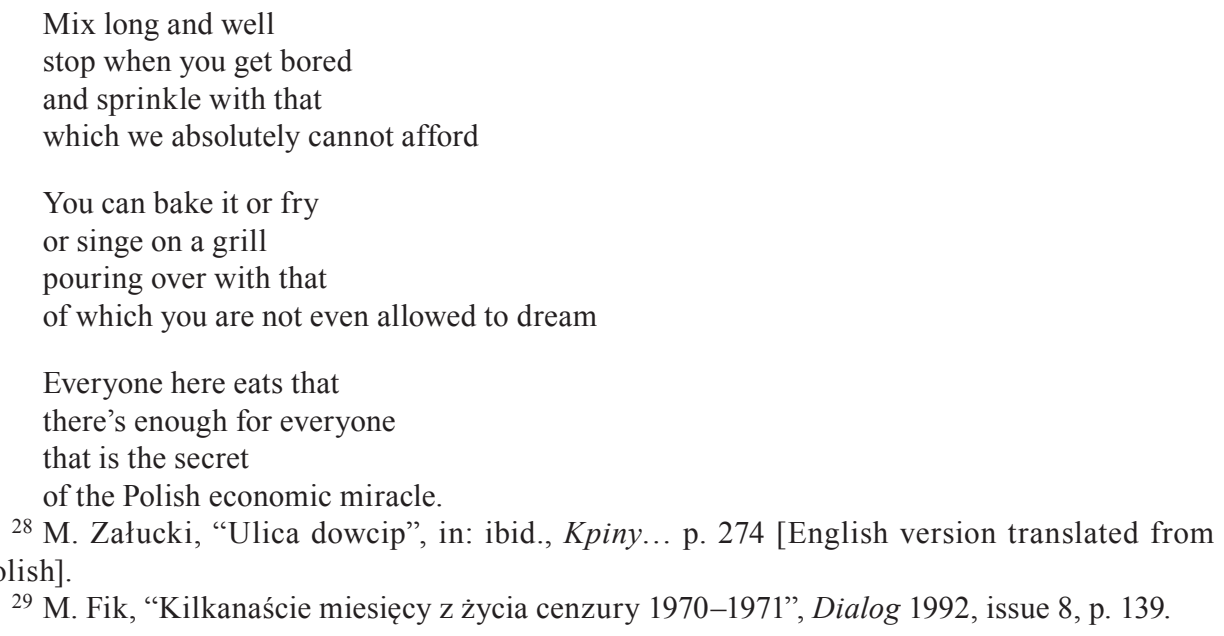

${ }^{29}$ M. Fik, “Kilkanaście miesięcy z życia cenzury 1970-1971”, Dialog 1992, issue 8, p. 139. 
Komu do śmiechu published by Wydawnictwo Iskry, but he decided that it could not include Załucki's other poem entitled Wykręty historyczne, as it featured "excessive criticism" 30 .

The poems Ulica Dowcip and Przepis po polsku were written in 1967. The comedian tried presenting them on a television show 23 minuty z Zatuckim. The State Archive in Gdansk includes a document by the Chief Bureau for Control of Press, Publications, and Performances with an overview of the major interventions in the television show from February and March of 1967. Censors' notes indicate that in the script submitted for verification only two works were challenged: Ulica Dowcip and Przepis po polsku ${ }^{31}$. The decision received a laconic justification: "due to the huge audience" 32 .

My academic duty should require me to make a reservation that it might prove very possible that in the rather non-aggressive forms of comicality preferred by Marian Załucki I found a bit more than they actually include. However, I would like to remind you that "to read more than the author wrote is the constant function of a reader, maintaining the illusion of an eternally renewing richness of old literature." ${ }^{33}$ Comical works constitute a special proof of past times. ${ }^{34}$ It is necessary to engage in more detailed studies of satire and comedy shows, which were an important aspect of the cultural life of the People's Republic of Poland. Comicality utilised by Socialist realist comedians for maintaining discipline within the working class became in the following decades, paradoxically, a space of freedom. Marian Załucki's personal attitude-the party-nominated "engineer of souls"-towards the new system of governance was best expressed in a poem entitled Do celników:

You peer into my chests and cases

While I'm smuggling socialism out in my arse ${ }^{35}$

Significantly enough, the work has never been published. Załucki recited it only among his most trusted friends. ${ }^{36}$

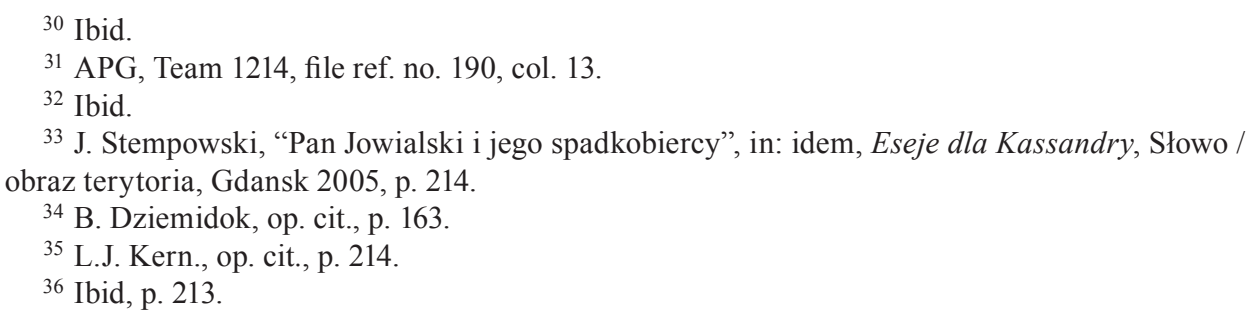




\section{Bibliography}

State Archive in Gdansk, Team 1214, file ref. no. 190, col. 13.

Alichnowicz Karol, „Miejsce dla kpiarza” satyra w latach 1948-1955, Universitas, Krakow 2006.

Duk Józef Adam, Z mej poetyckiej natury. Wiersze i fraszki Mariana Załuckiego, Wydawnictwo Astra, Lodz 2017.

Dziemidok Bohdan, O komizmie. Od Arystotelesa do dzisiaj, Monika Bokiniec (ed.), Słowo / obraz terytoria, Gdansk 2011.

Fik Marta, “Kilkanaście miesięcy z życia cenzury 1970-1971”, Dialog 1992, issue 8, pp. 134-145.

Głowiński Michał, "Ironia jako akt komunikacyjny”, in: Ironia, idem. (ed.), Słowo / obraz terytoria, Gdansk 2002, pp. 5-16.

Groński Ryszard Marek, “O nim jako ulubieńcu publiczności”, http://zalucki.net/wspomnienia/48-o-nim-jako-ulubiencu-publicznosci (accessed on: 11.10.2017).

Groński Ryszard Marek, Puszka z Pandora, Polska Oficyna Wydawnicza „BGW”, Lodz 1991.

Hemar Marian, Awantury w rodzinie, Wydawnictwo LTW, Łomianki 2008.

Kern Ludwik Jerzy, "Marian Załucki”, in: idem, Moje Abecadłowo, Wydawnictwo Literackie, Krakow 2003, pp. 210-214.

Stempowski Jerzy, "Pan Jowialski i jego spadkobiercy", in: idem, Eseje dla Kassandry, Słowo / obraz terytoria, Gdansk 2005, pp. 213-278.

Strajkowy Biuletyn Informacyjny "Solidarność", 25 August 1980, issue 4, http://www.wszechnica.solidarnosc.org.pl/?page_id=724 (accessed on: 13.10.2017).

Załucki Marian, A nie mówiłem?, Iskry, Warsaw 1961.

Załucki Marian, Czy pani lubi Załuckiego?, Iskry, Warsaw 1967.

Załucki Marian, Kpiny i kpinki, Kern Ludwik Jerzy (ed.), Wydawnictwo Literackie, Krakow 1985.

Załucki Marian, Przejażdżki wierszem, Czytelnik, Warsaw 1954.

Katarzyna Smyczek

\section{Irony, self-mockery, and ironic turns of events. Marian Załucki's satirical performances}

\section{(Summary)}

The article offers an analysis of the works of Marian Załucki (a Polish comedian, poet, children's literature writer, and author of books: Przejażdzki wierszem, Uszczypnij muzo, Ojczyste kpiny!, A nie mówiłem?, Niespokojna czaszka, Przepraszam żartowałem, Czy lubi pani Zaluckiego?), and constitutes an attempt at presenting the specificity of the comedy scene in the PRL.

Keywords: Załucki Marian, satire, comedy show, censorship in the People's Republic of Poland, Borderlands 